\title{
Colorectal Neuroendocrine Tumor TNM Finding v8
}

National Cancer Institute

\section{Source}

National Cancer Institute. Colorectal Neuroendocrine Tumor TNM Finding v8. NCI

Thesaurus. Code C135161.

A finding about one or more characteristics of a colorectal neuroendocrine tumor, following the rules of the TNM AJCC v8 classification system. This classification system applies to colorectal "carcinoid" tumors (neuroendocrine tumor G1 and G2, and rare-well differentiated G3). It does not apply to high-grade neuroendocrine carcinomas and mixed adenoneuroendocrine carcinomas of the colon and rectum. (from AJCC 8th Ed.) 